\title{
Nature or Nurture: Why do 401(k) Participants Save Differently than Other Workers?
}

\author{
Karen M. Pence ${ }^{1}$ \\ Karen.Pence@frb.gov \\ Federal Reserve Board of Governors \\ June 2002
}

\begin{abstract}
Participants in 401(k) plans are more likely than other workers to list "retirement" as their main reason for saving, to hold individual retirement accounts and to invest in the stock market. There are two possible reasons for these differences: (1) workers who like to save choose to participate in the program; or (2) 401(k) participation educates workers about investing. I disentangle these explanations using the 1983-1989 Survey of Consumer Finances panel. I find that 401(k) participants have a greater interest in saving for retirement than other workers, suggesting that extrapolating from their saving behavior to that of the workforce at large could be misleading. 401(k) participation also appears to increase awareness of retirement saving, but the gains are largest among workers who already prioritize retirement saving.
\end{abstract}

\footnotetext{
${ }^{1}$ I am grateful to Len Burman, Bill Gale, and my Federal Reserve Board colleagues, especially Carol Bertaut, Julia Coronado, Karen Dynan, Greg Grothe, Brian Knight, Andreas Lehnert, and Michael Palumbo, for helpful comments on this paper. Arthur Kennickell, Ana Aizcorbe, and Kevin Moore provided invaluable assistance with the Survey of Consumer Finances. The views expressed in the paper are mine alone and do not necessarily represent those of the Federal Reserve Board or its staff.
} 
Although a large literature has examined whether the 401(k) program affects the amount of money that workers save, fewer authors have examined whether the program affects how and why workers save, despite the striking differences in the saving behavior of 401(k) participants and other workers. For example, when asked to characterize their saving behavior, 401(k) participants are more likely to name "retirement" as their main reason for saving and more likely to have a long time horizon for saving. They are more likely to have an individual retirement account (IRA) and to hold individual stocks outside of their retirement plans. Participants are also more skilled at estimating their marginal tax rate and at calculating interest rates.

Two possible reasons underlie this divergence. One reason is selection: if employers offer benefits that their employees want, 401(k) participants should have an interest in saving for retirement. In addition, workers who are financially savvy, who enjoy controlling their investments, and who are comfortable taking risk may prefer the format of a 401(k) plan, where the worker is responsible for the investment decisions, over the format of a defined benefit plan, where the employer bears this responsibility.

Alternatively, the act of participating in the 401(k) program may change saving behavior. One possible avenue is financial education: many employers provide seminars and newsletters focused on retirement saving in an attempt to boost participation in the program. In addition, workers may gain financial savvy by deciding how to allocate their contributions among different investments and by monitoring these investments over time.

As the United States moves towards a system in which individuals are responsible for managing their own retirement saving, disentangling these explanations has become increasingly important. Defined benefit pension plans, in which the employer manages the investments, are being supplanted by defined contribution plans in which workers generally control the investment decision. Even more fundamentally, in December 2001 the President's Commission to Strengthen Social Security advocated adding a voluntary personal retirement account component to Social Security.

How and why individuals save is an important factor in evaluating these trends. If $401(\mathrm{k})$ participants have a greater innate interest in saving than the rest of the population, their saving behavior may prove a poor guide for how the saving behavior of other groups would respond to retirement savings programs. On the other hand, evidence that workers can "learn to save" 
through their participation in the 401(k) or similar programs may assuage concerns that workers do not have the financial skills to assume primary responsibility for their financial security in retirement.

In this paper, I disentangle these two explanations using the 1983-1989 Survey of Consumer Finances panel. I select two groups of households: those who were participating in a 401(k) plan in 1989 and those who were participating in a different retirement saving plan, such as a defined benefit pension, in 1989. I identify the role that selection plays in the saving behavior of 401(k) participants by comparing the behavior of the two groups in 1983, six years earlier, when the $401(\mathrm{k})$ program was in its infancy. I identify the role that financial education plays by comparing the change in the saving behavior of the groups over the 1983-1989 period as 401(k) participants gained experience with the program.

I document, as have other researchers, that 401(k) participants and other workers differ in demographic characteristics that are correlated with saving behavior, such as education and income. However, even after controlling for these differences, I find that workers with a greater interest in saving for retirement are more likely to select into the 401(k) program. Although other authors have conjectured about this selection mechanism, none have provided direct evidence of its existence.

Workers with a greater tolerance for risk, however, do not appear to select into the program. If anything, 401(k) participants appear to have a lower tolerance for risk than other workers, consistent with the notion that risk-averse workers are more interested in saving. These risk coefficients are not estimated precisely, limiting my ability to draw strong conclusions. Nonetheless, the overall pattern of differences in demographic characteristics and in attitudes towards saving suggests that the saving behavior of 401(k) participants may not be a useful guide for how the population as a whole would respond to individual investment accounts.

In addition, the results only provide weak support for the idea that participation in the 401(k) program changes workers' attitudes towards saving. Participation appears to heighten awareness of retirement saving, but the gain stems disproportionately from reinforcing this interest among workers for whom retirement saving was already a priority. Furthermore, the relative risk preferences of the two groups do not change over time. Although caution is warranted in extrapolating from these findings, given the small sample sizes and the noisy measures of saving attitudes used in the analysis, the overall results suggest that the education 
provided by the program does not have a dramatic effect on the saving attitudes of participants over time.

\section{The 401(k) Program}

The 401(k) program was designed to encourage personal saving for retirement. Eligible workers can deposit a percentage of their before-tax pay in investments such as mutual funds or guaranteed investment contracts. These contributions are deducted automatically from the worker's paycheck. Earnings and contributions are taxed only when assets are withdrawn at retirement; earnings compound at the pre-tax rate in the interim. Most employers match all or part of employee contributions, yielding an even higher rate of return. However, not all workers can benefit from these incentives, since workers are eligible for the program only if their employer offers a plan. ${ }^{2}$

Over time, the 401(k) program has become the dominant U.S. employer-provided retirement plan. While 401(k) plans were originally seen as supplements to defined benefit plans, by 1998 over half of 401(k) participants had only 401(k) coverage. ${ }^{3}$ By 2001, assets in 401(k) plans exceeded those held in defined benefit plans. ${ }^{4}$

A large literature has investigated whether workers have responded to the incentives of the 401(k) program by increasing the amount of money that they save. ${ }^{5}$ A much smaller literature has considered the focus of this paper - whether the program affects how and why participants save. Both literatures, however, face the same fundamental identification problem. If 401(k) participants save differently than other workers, does this imply that the program affects their behavior? Or do workers who want to save select into the program?

The selection argument is straightforward. Presumably employers offer benefits that are valuable to their employees, and workers seek out jobs that offer benefits that they want. Workers who want to save for retirement will search for jobs that offer the 401(k) program or

\footnotetext{
${ }^{2}$ Technically, 401(k) plans are only available to the employees of for-profit companies. Throughout this paper I classify 403(b) plans, which are the equivalent of 401(k)s in the non-profit sector, and other thrift plans as 401(k) plans.

${ }^{3}$ U.S. Department of Labor (1998) Table D5.

${ }^{4}$ Estimated defined benefits assets in 2001 were $\$ 1,819$ billion (Flow of Funds Accounts), while estimated 401(k) assets were \$1,974 billion (Cerulli Associates).

${ }^{5}$ Poterba, Venti, and Wise $(1995,1996,1998)$ conclude that most 401(k) contributions represent new saving, while Engen, Gale, and Scholz (1994, 1996) and Engen and Gale (2000) find that most contributions are offset by decreases in other saving. See also Pence (2002), Engelhardt (2001), and Benjamin (2002).
} 
will pressure their current employer to adopt it. In fact, according to the 2002 Small Employer Retirement Survey, the main reason why small firms offer a plan is "competitive advantage for the business in employee recruitment and retention" and the main reason why they don't is "employees prefer wages and/or other benefits."

In contrast, there are several possible mechanisms by which the 401(k) program might influence how and why workers save. First, many firms provide direct financial education to their workers through seminars, newsletters, or summary plan descriptions. Employers may offer this education in an attempt to boost participation rates among low-income workers, since a retirement plan can lose its tax-advantaged status if low- and high-income workers do not participate at comparable rates. Bayer, Bernheim, and Scholz (1996) find that firms that offer 401(k) plans are more likely to provide financial seminars than are other firms, and that this education increases the probability that workers participate in and contribute to their $401(\mathrm{k})$ plans. Bernheim and Garrett (2002) also find that employer-provided financial education increases saving for retirement.

Second, financial institutions that administer 401(k) plans may provide education in an attempt to boost demand for their products. Bernheim (2002) notes that the surge in individual retirement account (IRA) contributions in the early 1980s has been partially attributed to aggressive marketing and promotion on the part of financial institutions.

Third, workers may gain "learning by doing" financial education through the process of participating in a $401(\mathrm{k})$ plan. Since the $401(\mathrm{k})$ program reduces the fixed costs of investing, these workers might not have invested, and thus gained this education, in the program's absence. Specifically, the program reduces the fixed cost by limiting the number of investment options to a manageable few and by allowing small investments over time, instead of a large initial investment. Workers may also receive advice from colleagues who face the same set of choices. Weisbenner (1999) finds that workers who control the allocation of their retirement assets are more likely to hold stocks outside of their retirement accounts, which he interprets as evidence of learning-by-doing education.

Finally, the mere presence of a retirement plan can change norms about saving. The provision of a retirement benefit may be interpreted as a signal from the employer that saving for retirement is important. Workers' attitudes about saving may also be influenced by the decisions

\footnotetext{
${ }^{6}$ See the Employee Benefit Research Institute (2002) for details.
} 
and attitudes of their peers. For example, Duflo and Saez (2000) find evidence suggesting that a worker's decision to participate in a 403(b) plan and her choice of fund vendor are affected by the decisions of her colleagues. These behavioral dynamics, along with the other mechanisms already discussed, suggest that either selection or financial education could plausibly explain the differences in the saving behavior of $401(\mathrm{k})$ participants and other workers.

\section{Estimation Strategy and Identification}

I select a group of households that participated in the 401(k) program in 1989. I identify the role that selection plays in their saving behavior by examining their saving behavior six years earlier in 1983. I identify the role that financial education plays in their saving behavior by examining their behavior in 1989 conditional on their behavior in 1983. This approach assumes that the financial education provided by the 401(k) program to $1989401(\mathrm{k})$ participants did not affect their saving behavior six years earlier in 1983. I discuss the evidence behind this assumption in this section. In addition, I examine whether the demographic differences between 401(k) participants and other workers could partially account for differences in their saving behavior.

Did the 401(k) program affect saving behavior in 1983? Given the history of the program, it seems unlikely that the 401(k) program itself affected saving behavior in 1983. Although Congress technically authorized the program in 1978, firms did not add programs until the IRS clarified in 1982 which regulations they should follow. In 1983, the program was still small, with 4 million workers participating in 1,700 plans. Only 8 percent of the workforce was eligible for the program, and only 38 percent of these eligible workers participated. In contrast, by 198917 million workers participated in 83,301 plans; by 1992, 42 percent of the workforce was eligible, and 65 percent of those eligible participated. ${ }^{7}$

The media also largely ignored the 401(k) program in 1983. Media attention serves as a gauge of public awareness of an issue and may also, in turn, increase awareness and influence behavior. In 1983 the media was focused on individual retirement accounts (IRAs), which

\footnotetext{
${ }^{7}$ Plan and participant statistics are based on Department of Labor Form 5500 data; see Andrews (1992) Table 8.2 for 1983 statistics and United States Department of Labor (2001) Table E23 for 1989 statistics. Eligibility and participation rate statistics are based on the Current Population Survey; see Rockwell (1986) Table 8 for 1983 statistics and Bassett, Fleming, and Rodrigues (1998) Table 1 for 1992 statistics.
} 
enjoyed a massive surge in popularity after eligibility was expanded in $1982 .{ }^{8}$ As noted earlier, this media coverage both reflected and contributed to the growth in IRA participation. ${ }^{9}$

To document the relative amount of media attention paid to the two programs, I searched 11 major financial publications for mentions of "401(k)" and "individual retirement account" in both 1983 and 1989. ${ }^{10}$ In 1983, there were only 14 mentions of "401(k)" but 491 mentions of "individual retirement account." In 1989, coverage was more balanced, with 218 mentions of "401(k)" and 617 mentions of "individual retirement account."

Although the 401(k) program does not appear to have affected saving behavior in 1983, its predecessor, the after-tax thrift plan, may have. Many early 401(k) plans were conversions of these after-tax thrift plans, which were similar to 401(k) plans with the notable exception that they permitted after-tax, rather than pre-tax, contributions. Engen, Gale and Scholz (1996) suggest that 39 percent of 401(k) plans and 65 percent of participants in 1985 resulted from thrift plan conversions.

Ultimately, whether financial education provided by after-tax thrift plans affected 1983 saving behavior is an empirical issue. In my sample, 17 percent of $1989401(\mathrm{k})$ participants and 6 percent of participants in other retirement plans participated in a thrift plan in 1983. Although these households potentially pose a challenge to the identification assumption, dropping them from the sample, as shown later in the paper, does not change the results.

\section{Could demographic differences between 401(k) participants and other workers explain} differences in their saving behavior? 401(k) participants may have different demographic characteristics than other workers, which may partly explain why their saving behavior differs. For example, if 401(k) participants are younger than other workers, they may be less interested in saving for retirement. In addition, demographic characteristics may affect the rate at which saving behavior changes over time.

To minimize the role that demographic characteristics play in the comparison, I limit the sample to households in which at least one spouse was participating in an employer-sponsored retirement program in 1989. I assume that these workers, who are presumably employed in

\footnotetext{
${ }^{8}$ The 1981 tax law allowed all taxpayers, regardless of pension coverage or income, to make tax-deductible IRA contributions. Over the 1981-1982 period, the number of IRA accounts jumped from 3.4 million to 12 million while contributions grew from $\$ 5.2$ billion to $\$ 29.2$ billion. See Rockwell (1986) p. 392.

${ }^{9}$ See Bernheim (2002) p. 1222

${ }^{10}$ The publications are the New York Times; the Washington Post; the Wall Street Journal; Newswe ek; Time; Fortune; Business Week; Forbes; Money; the Associated Press; and United Press International.
} 
"good" jobs that offer benefits, are different from other workers in a way that I cannot control for fully in a regression specification. I also delete households in which the head was older than 64 in 1989, since these households have a retirement option that may distort their saving behavior.

Saving behavior may reflect circumstance as well as demographic characteristics and preferences. To ensure that sample members are in comparable circumstances across time, I keep only households in which at least one spouse was working full-time but was not selfemployed in both 1983 and 1989. Only these types of households are potentially eligible for the 401(k) program, since the program is generally not available to workers who are self-employed or unemployed. Furthermore, since spouses may differ in their assessment of a household's saving behavior, I keep only households in which the same person answered the survey in both years.

Even after imposing these sample restrictions, 401(k) participants have different demographic characteristics than households in the control group. Table 1 presents the characteristics both of the sample used in the estimation and of the sample weighted to reflect the population as a whole. Since the SCF oversamples wealthy households, these estimates can differ. As shown in the table, 401(k) participants have more education and income than other workers and are less likely to belong to a racial minority. They are also employed at different types of jobs: they are more likely to work in professional occupations, more likely to work at large firms, and less likely to belong to a union. Since these demographic differences may be correlated with saving behavior, I control for them in the estimation.

\section{The Survey of Consumer Finances}

The Federal Reserve Board has conducted the Survey of Consumer Finances (SCF) every three years since 1983. The survey is designed to provide a representative picture of the wealth of American households at a point in time. The 1989 survey is unique because it includes both a panel and a cross-sectional component. Of the 3,143 households in the 1989 survey, 1,479 were interviewed previously in the 1983 survey.

High-wealth individuals are over-sampled in the panel, as in all waves of the SCF, because they hold a disproportionate share of wealth. In addition, because sample members had

\footnotetext{
${ }^{11}$ I am grateful to Cathy Tunis for conducting this search.
} 
to live in an American household with a head older than 21 in 1983, the panel is not representative of young households in 1989 or of recent immigrants.

One disadvantage of the SCF panel is its small sample size. The sample restrictions imposed in this paper reduce the sample size even further. As noted above, the SCF oversamples wealthy households, who are disproportionately self-employed and elderly. In an additional eight percent of households, the survey respondent changed between 1983 and 1989. The final sample consists of 169 households in which at least one spouse participated in the 401(k) program in 1989 and 282 households in which at least one spouse participated in a retirement savings program other than the 401(k) program in 1989.

The other disadvantage of the SCF panel is that it identifies 401(k) participating households but not households who are eligible and choose not to participate. ${ }^{12}$ This restriction implies that the selection specification captures a worker's decision to work at a firm that offers the program as well as his decision to participate if eligible. It also implies that the comparison group includes some households who are eligible for but not participating in the 401(k) program, since many plans, especially in the early years, were added on to existing defined benefit pensions. While this restriction does not affect the questions of interest in this paper, it means that the results do not shed light on the contentious issue of whether 401(k) eligibility is correlated with saving preferences. ${ }^{13}$

A sizeable advantage of the SCF, however, is the tools that it provides for handling missing values. In the SCF, as in most surveys, some respondents either do not know the answer to some questions or refuse to answer them. The SCF provides three replicates of every observation, each of which includes a different value for every piece of missing data. These values are drawn from a distribution of possible responses. Estimation procedures are run separately on each replicate, and the final statistic is the average of the three sets of coefficients, with an adjustment made for the imputation uncertainty. For more details on this technique, known as repeated-imputation inference, see Kennickell (1998) or Little (1992). All point estimates and standard errors displayed in this paper were calculated using repeated-imputation inference techniques.

\footnotetext{
${ }^{12}$ Later SCF waves allow for easier classification of eligible nonparticipants. See Pence (2002) for details.
} 


\section{Measures of saving behavior}

There are at least three possible reasons why workers might select into the $401(\mathrm{k})$ program:

(1) Participants may be interested in saving for retirement.

(2) Participants may want to choose their retirement investments themselves rather than have an employer choose them in a defined benefit plan. Specifically, participants may be willing to bear the greater financial risk associated with a 401(k) plan in exchange for a higher expected return. However, since risk-averse households have a greater interest in saving, it is also possible that $401(\mathrm{k})$ participants are willing to bear less risk with their investments than other workers.

(3) Participants may have more financial savvy and are thus better able to exploit and understand the advantages of a $401(\mathrm{k})$ program.

Analogously, through their participation in the 401(k) program, workers may learn about the importance of saving for retirement, gain confidence in taking risk with their portfolios, or accumulate general financial knowledge.

I assess these hypotheses using three kinds of measures. First, I examine respondents' self-reported descriptions of their main reasons for saving, the amount of risk they are willing to take with their investments, and how long they are willing to tie up their money. Second, I examine investment holdings that may be correlated with either preferences or financial education. Finally, I assess respondents' awareness of their marginal tax rate and their ability to perform complex interest rate calculations.

The list below shows the saving behavior measures and the years for which they are available, grouped by hypothesis. I use questions asked in 1983 to assess the role that selection plays in 401(k) participant saving behavior and use the questions asked in both years to assess the role played by financial education.

\section{Measures of interest in saving for retirement:}

(1) Is "retirement" the respondent's main self-reported reason, or one of his top two reasons, for saving (1983 \& 1989)?

(2) Does the respondent own an IRA (1983 \& 1989)?

\footnotetext{
${ }^{13}$ See Poterba, Venti, and Wise (1996) and Engen, Gale, and Scholz (1996) for two different points of view on this issue.
} 


\section{Measures of willingness to take risk with investments:}

(1) Is the respondent willing to take risk with his investments in order to earn a higher return (1983 \& 1989)?

(2) Is the respondent willing to tie up his money in order to earn a higher return (1983 only)?

(3) Does the respondent hold individual stocks outside of his retirement plan (1983 \& 1989)?

\section{Measures of financial savvy:}

(1) How accurately can the respondent estimate his marginal tax rate (1983 only)?

(2) How accurately can the respondent perform complex interest rate calculations (1983 only)?

(3) Does the respondent almost always pay off his credit card balance in full each month (1983 and 1989)?

(4) Has the respondent been denied credit in the past five years (1983 and 1989)?

While all these measures are correlated with the underlying parameter of interest, some measures, such as the credit card and denied credit questions, undoubtedly reflect circumstances as well as financial savvy. Adding demographic controls to the specification may help eliminate the role played by circumstances. In addition, the self-reported saving behavior measures may be noisy if households have a limited ability to assess their own saving behavior. However, these questions correlate in sensible ways with age, income, and other covariates. As households age, for example, they are more likely to name "retirement" as their main reason for saving. Furthermore, Samwick (1996) shows that households' stated time horizons for saving in the SCF are correlated with structural estimates of their time preference.

All measures are dummy variables set to "1" if the answer to the question is "yes," except the marginal tax rate estimates and interest rate calculations, which are continuous measures. For the marginal tax rate estimate, I use the absolute value of the difference between the respondent's estimate of his federal marginal tax rate and the estimate computed by the NBER TAXSIM model. ${ }^{14}$

For the interest rate measure, the SCF asks respondents for their estimate of the amount of finance and carrying charges they would incur if they bought a $\$ 1,000$ room of furniture and financed it over a one-year period. As a follow-up question, the survey asks what interest rate is implied by these finance and carrying charges. Following Maki (1996), I define the interest rate measure as

absolute value(ln(correct answer)-ln(respondent's answer)).

\footnotetext{
${ }^{14}$ I am grateful to Kevin Moore for providing this data.
} 
Because this question implicitly requires respondents to calculate amortization tables in their heads, even financially sophisticated may have difficulty answering it, casting doubt on its usefulness. However, the question correlates with level of education, and Maki (1996) uses the same measure to demonstrate that financially savvy households were more likely to substitute tax-deductible mortgage debt for consumer debt after the Tax Reform Act of 1986 eliminated the consumer debt tax deduction. For both the interest rate and the marginal tax rate estimates, a lower score indicates a closer correspondence between the correct answer and the respondent's answer.

Table 2 provides the means for the saving measures for both 1983 and 1989. In both years, 401(k) participants are more interested in saving for retirement, somewhat more willing to take risk with their investments and more financially savvy than other workers, although many of the differences are statistically insignificant. Over time, both groups of households become increasingly interested in saving for retirement and more reluctant to take risk with their investments, underscoring the importance of using a control group in the estimation. The exact definitions of these variables and all others are contained in the data appendix.

\section{Results}

Selection. To examine the role that selection plays in the saving behavior of 401(k) participants, I look at workers' saving behavior in 1983, before participation in the program could have affected their attitudes and behavior. I use the following specification:

$\{$ measure of 1983 saving behavior $\}=\alpha+\gamma\{1989401(\mathrm{k})$ participant $\}+\mathrm{X} \beta+\varepsilon$.

If the identification assumption is true - namely, that the 401(k) program did not provide any financial education to future participants in $1983-\gamma$ captures the role played by selection in the difference between the saving behavior of $401(\mathrm{k})$ participants and that of participants in other retirement plans.

The matrix of explanatory variables $X$ includes characteristics of the household head that may be correlated with saving behavior: age in 1989, log income in 1983, dummies for high school graduate, college education, and graduate education, a dummy for "not white," and a dummy for a self-employed spouse in 1983. It also includes characteristics of the job that 
provided the retirement plan coverage in 1989 - the occupation, industry, firm size, and unionization status - since workers in some occupations are more likely to have the opportunity to participate in the 401(k) program. Finally, I include a dummy for married households in 1989; married couples are more likely to fall into the 401(k) category because a household is defined as a 401(k) participant if either spouse participates. All variables are defined in the data appendix. For simplicity, I use linear probability models with Eicker-White robust standard errors throughout this paper. Probit models produce similar results.

Table 3 displays the parameter $\gamma$ from equation (1) for an assortment of specifications that use different saving measures as the dependent variable. ${ }^{15}$ I show the specifications both with and without the sample weights. If the model is properly specified, including sample weights will not affect the coefficients but is likely to increase the standard errors. However, if the wealthy households who are oversampled in the SCF save in a different manner than less affluent households, and if the regression does not control adequately for these differences, the weighted regressions may provide a more accurate representation of the behavior of the nation as a whole.

Taken together, the specifications suggest that 401(k) participants have a greater innate interest in saving for retirement than other workers. In the unweighted specifications, 401(k) participants are seven percentage points more likely to list "retirement" as their main reason for saving and are eleven percentage points more likely to hold an IRA. The first result is statistically significant at the ten percent level; the second, at the one percent level. The weighted specifications indicate that $401(\mathrm{k})$ participants are six percentage points more likely to list "retirement" as their main reason for saving and eight percentage points more likely to hold an IRA. Due to smaller coefficients and larger standard errors, the "retirement" coefficient is statistically significant at the twenty percent level and the IRA coefficient is statistically significant at the ten percent level.

The "risk" set of specifications does not suggest that households who enjoy controlling their investments select into the 401(k) program. Rather, they are consistent with models in which risk-averse households have a greater desire to save, although none of the results are statistically significant at conventional levels. In the unweighted regressions, 401(k) participants

\footnotetext{
${ }^{15}$ In the Appendix table, I display the complete set of coefficients for two specifications. The other specifications are available from the author upon request.
} 
are four percentage points less likely to take risk with their investments than other workers, but are equally likely to hold stocks. In the weighted regressions, 401(k) participants are three to eight percentage points less likely to take risk with their investments and eight percentage points less likely to hold stocks. The last result is statistically significant at the 12 percent level. In both sets of specifications 401(k) participants are more willing to tie up their money to earn higher returns, but this result is consistent with two possibilities. Participants could be more willing to take risk, but they could also have a low discount rate, which is correlated with interest in saving.

In terms of financial savvy, the two groups are virtually indistinguishable in terms of whether they pay their credit cards on time and whether they have been turned down for credit. Furthermore, 401(k) participants do slightly worse than their counterparts on the marginal tax rate and interest rate quizzes after demographic controls are added to the specification. ${ }^{16}$

Financial education. To examine the role that financial education plays in the saving behavior of 401(k) participants, I look at their saving behavior in 1989, controlling for their earlier saving behavior in 1983. I use the following specification:

\{measure of 1989 saving behavior $\}=\alpha+\gamma\{1989401(\mathrm{k})$ participant $\}+\phi\{$ measure of 1983 saving behavior $\}+X \beta+\varepsilon$

where $\gamma$ captures the effect of financial education, $\phi$ controls for pre-existing differences in saving taste, and the matrix of explanatory variables $X$ includes age in 1989, log income in 1983, $\log$ income in 1989, and dummies for high school graduate, college education, graduate education, "not white," self-employed spouse in 1983, self-employed spouse in 1989, occupation, industry, firm size, union status and married in 1989.

Table 4 shows weighted and unweighted results from the financial education specification. Over time, the behavior of 401(k) participants and the comparison group diverges only in their interest in saving for retirement. In 1989, 401(k) participants were 8 percentage points more likely than the comparison group to list "retirement" as their top reason for saving and 11 or 13 percentage points more likely to list it among their top two reasons, controlling for

\footnotetext{
${ }^{16}$ Recall that positive values for this measure indicate a worse score.
} 
their answer in 1983. They were also more likely to have an IRA, but this coefficient is statistically insignificant and in 1989 may not capture interest in retirement saving, since IRA eligibility was scaled back in 1986 and since IRAs and 401(k) accounts are substitutes for most households.

For the other measures available in both years, the change in the behavior of the two groups over time is virtually indistinguishable. The weighted regression suggests that controlling for stock ownership in 1983, 401(k) participants were six percentage points more likely to own stocks in 1989 than households in the comparison group, but this coefficient is not statistically significant. All other coefficients are essentially zero.

Robustness tests. If participation in the 401(k) program increases interest in retirement saving, households that have participated in the program for several years should display a greater increase in interest in retirement saving than new participants. As a robustness check on the earlier results, I replace the "401(k) participant" dummy in equation (2) with " $401(\mathrm{k})$ participant" interacted with measures of how long the worker has participated in her current 401(k) plan. ${ }^{17}$ To control for a possible correlation between saving attitudes and job tenure, I also include in the specification the number of years that the worker has been employed in her current job. As before, the specification also controls for the age of the household head.

The results, shown in Table 5, indicate that workers with one or two years of participation were only four percentage points more likely than workers in the comparison group to list "retirement" as their main reason for saving in 1989, conditional on their 1983 answer. In contrast, workers who participated for three or four years were fourteen percentage points more likely to list "retirement;" workers who participated for five or six years were nineteen percentage points more likely to list it. Using the "top two reasons for saving" measure as the dependent variable yields a similar relationship between length of participation and increase in interest in retirement saving.

Anomalously, workers with more than six years of participation, whose plan is presumably a conversion from an after-tax thrift plan or a profit-sharing plan, were four percentage points more likely to list retirement as their main reason for saving, substantially less than workers with five to six years of participation. Whether this result reflects an unusual

\footnotetext{
${ }^{17}$ Since the weighted and unweighted versions of this specification are similar, I display only the unweighted results here.
} 
feature of these workers, or whether any financial education they received was absorbed by the 1983 saving attitude dummy, is unclear. Alternatively, workers' desire to save for retirement may be satiated after a few years of participation. I test the sensitivity of the results to removing these workers later in the paper.

Two different dynamics could underlie this increase in interest in retirement saving among 401(k) participants. Due to the financial education provided by the 401(k) program, households who did not prioritize retirement saving in 1983 could have realized its importance by 1989 . Alternatively, the 401(k) program could reinforce the importance of retirement saving among households for whom retirement saving was already a priority. To separate out these explanations, I allow the coefficient on the $401(\mathrm{k})$ participant variable to vary with the respondent's reasons for saving in 1983. Thus, I can distinguish between the program's effect on households who listed "retirement" as their main reason for saving in 1983 and on those who listed another reason.

Table 6 displays the results of this specification. The omitted category is households in the control group who did not list "retirement" as their main reason for saving in 1983. The other three rows list the probability that a household in a given group listed "retirement" as its main reason for saving in 1989, relative to this omitted group and controlling for demographic characteristics. The first row indicates that 401(k) participants who did not list "retirement" in 1983 were four percentage points more likely to list it in 1989 than the omitted group. The second row indicates that control group members who listed "retirement" in 1983 were eight percentage points more likely to list it in 1989. The third row indicates that 401(k) participants who listed "retirement" in 1983 were 38 percentage points more likely to list it in 1989. Thus, they were 34 percentage points more likely to list it than other 401(k) participants, and 30 percentage points more likely to list it than control group members who also identified it as a priority in 1989. I obtain similar results when I use "retirement in top two reasons for saving" as the dependent variable. ${ }^{18}$ These findings suggest that the 401(k) program increases interest in retirement saving by reinforcing this interest among workers who already have it, rather than by converting workers who have different saving priorities. ${ }^{19}$

\footnotetext{
${ }^{18}$ Weighted regressions not shown here yield essentially the same coefficient estimates.

${ }^{19}$ For the other saving measures, I also experimented with allowing the 401(k) participant coefficient to vary with the worker's answer in 1983. None of these specifications suggested that the coefficient differed according to the worker's 1983 answer.
} 
Finally, I examine the robustness of my results to excluding households who participated in a thrift plan in 1983. These households potentially received financial education from a 401(k) plan or a similar thrift plan in 1983, thus threatening the identification assumption. I use two different methods to exclude these households. In the first test, I drop the 44 households who stated in 1983 that they participated in an after-tax thrift plan. In the second test, I drop the 63 households who said that they had participating in their 401(k) plan since before $1983 .{ }^{20}$ As shown in Table 7, my results are essentially unchanged when I impose these sample restrictions, although the drop in sample size deteriorates the statistical significance of some of the coefficients. After dropping households who participated in a thrift plan in 1983, for example, the "main reason for saving is retirement" coefficient in the selection equation is now statistically significant at the 11 percent level.

\section{Conclusion}

These results indicate that 401(k) participants differ from the rest of the workforce, both in their demographic characteristics and in their innate interest in saving for retirement. Although it is not surprising that workers who value saving for retirement choose to participate in the 401(k) program, this paper is among the first to document this fact. ${ }^{21}$ This difference in interest in retirement saving implies that extrapolating from the saving behavior of $401(\mathrm{k})$ participants to that of the workforce at large can yield misleading conclusions.

The results also suggest that participation in the 401(k) program increases awareness of retirement saving, although whether this heightened awareness translates into higher actual levels of saving is not clear. Overall, though, the results provide only mild support for the idea that participation in the $401(\mathrm{k})$ program changes saving behavior.

Several caveats apply to these conclusions, of course. The results are estimated on a small sample and some of the saving measures are undoubtedly noisy. The magnitude and statistical significance of some coefficients might change with a larger sample and different measures. Furthermore, the specification is estimated on data from the early years of the 401(k) program. Today's 401(k) participants, who have had two decades of exposure to the program, may have benefited more from the program's educational aspects.

\footnotetext{
${ }^{20}$ Note that if a household participated in a thrift plan in 1983 and subsequently switched jobs, its earlier participation might not be captured by this measure.
} 


\section{References}

Andrews, Emily, "The Growth and Distribution of 401(k) Plans," in Trends in Pensions 1992, John A. Turner and Daniel J. Beller, eds., Washington: U.S. Department of Labor, Pension and Welfare Benefits Administration, 1992.

Bassett, William F., Michael J. Fleming, and Anthony P. Rodrigues, "How Workers Use 401(k) Plans: The Participation, Contribution, and Withdrawal Decisions," National Tax Journal, June 1998, 51, 263-89.

Bayer, Patrick, B. Douglas Bernheim, and John Karl Scholz, "The Effects of Financial Education in the Workplace: Evidence from a Survey of Employers," NBER Working Paper No. 5655, July 1996.

Benjamin, Daniel, "Does 401(k) Eligibility Increase Saving? Evidence from Propensity Score Subclassification," Journal of Public Economics, forthcoming.

Bernheim, B. Douglas, "Taxation and Saving," in Handbook of Public Economics, vol. 3, Alan J. Auerbach and Martin Feldstein, eds., Amsterdam: Elsevier, 2002.

Bernheim, B. Douglas, and Daniel M. Garrett, "The Effects of Financial Education in the Workplace: Evidence from a Survey of Households," Journal of Public Economics, forthcoming.

Duflo, Esther and Emmanuel Saez, "Participation and Investment Decisions in a Retirement Place: The Influence of Colleagues' Choices," Journal of Public Economics, forthcoming.

Employee Benefit Research Institute, "The 2002 Small Employer Retirement Survey (SERS) Summary of Findings," May 2002. Available at www.ebri.org.

Engen, Eric and William Gale, "The Effects of 401(k) Plans on Household Wealth: Differences Across Earnings Groups,” NBER Working Paper \#8032, December, 2000.

Engen, Eric, William Gale and John Karl Scholz, "Do Saving Incentives Work?," Brookings Papers on Economic Activity, 1994, 1, 85-151.

Engen, Eric, William Gale and John Karl Scholz, "The Illusory Effects of Saving Incentives on Saving," Journal of Economic Perspectives, Fall 1996, 58, 113-138.

Kennickell, Arthur B., "Multiple Imputations in the Survey of Consumer Finances," Federal Reserve Board of Governors Working Paper, September 1998.

${ }^{21}$ See also Pence (2002). 
Little, Roderick J.A., "Regression with Missing X's: A Review," Journal of the American Statistical Association, December 1992, 87(420), pp. 1227-1237.

Maki, Dean, "Portfolio Shuffling and Tax Reform," National Tax Journal, September 1996, 49(3), pp. 317-329.

Pence, Karen M., "401(k)s and Household Saving: New Evidence from the Survey of Consumer Finances,” FEDS Working Paper 2002-06, January 2002.

Poterba, James, Steven Venti and David Wise, "Do 401(k) Contributions Crowd Out Other Personal Saving?," Journal of Public Economics, September 1995, 58, 1-32.

Poterba, James, Steven Venti and David Wise, "How Retirement Saving Programs Increase Saving," Journal of Economic Perspectives, Fall 1996, 58, 91-112.

Poterba, James, Steven Venti, and David Wise, "Personal Retirement Saving Programs and Asset Accumulation: Reconciling the Evidence," in Frontiers in the Economics of Aging, University of Chicago Press, 1998, pp. 23-106.

Rockwell, Lynn, "Trends in Non-traditional Pension Coverage," in The Handbook of Pension Statistics 1985, Richard A. Ippolito and Walter W. Kolodrubetz, eds., Washington: United States Department of Labor, Office of Pension and Benefits Programs, 1986.

Samwick, Andrew, "Discount Rate Heterogeneity and Social Security Reform," Journal of Development Economics, October 1998, v. 57(1), pp. 117-46.

United States Department of Labor, Pension and Welfare Benefits Administration, "Abstract of 1998 Form 5500 Annual Reports," Private Pension Plan Bulletin No. 11, Winter 20012002, Washington, DC.

Weisbenner, Scott, "Do Pension Plans with Participant Investment Choice Teach Households to Hold More Equity?," FEDS Working Paper 1999-61, October 1999. 


\section{Data Appendix}

All variables are from the 1983-1989 Panel Survey of Consumer Finances unless otherwise indicated.

\section{Sample selection criteria:}

1. Same respondent in 1983 and 1989: x27206 in $(01,02,13)$

2. One spouse worked full-time but was not self-employed in 1983: $(x 50220=11)$ or $(\mathrm{x} 50240=11)$

3. One spouse worked full-time but was not self-employed in 1989: ((x4106=1) and (x4115 $>20))$ or $((x 4706=1)$ and $(x 4715>20))$

4. One spouse participated in a 401(k) plan or another retirement savings plan in 1989:

i. 401(k) participant: (X4216 in $(1,2))$ or $(X 4316$ in $(1,2)$ or $(X 4416$ in $(1,2))$ or (X4816 in $(1,2))$ or $(X 4916$ in $(1,2))$ or $(X 5016$ in $(1,2))$

ii. Participant in another plan: Not 401(k) participant and $(X 4203=2)$ or $(X 4303=2)$ or $(\mathrm{X} 4403=2)$ or $(\mathrm{X} 4803=2)$ or $(\mathrm{X} 4903=2)$ or $(\mathrm{X} 5003=2)$

5. Household head was younger than 65 in 1989: x14<65

\section{Measures of saving behavior:}

1. Household's main reason for saving is "retirement":

1983. $\mathrm{x} 50201=22$

1989. $\mathrm{x} 3006=22$

2. One of household's top two reasons for saving is retirement:

1983. $(x 50201=22)$ or $(x 50202=22)$

1989. $(x 3006=22)$ or $(x 3007=22)$

3. Household has an IRA:

1983. $x 50004>0$

1989. $\operatorname{sum}(\max (0, \mathrm{X} 3610), \max (0, \mathrm{X} 3620), \max (0, \mathrm{X} 3630))>0$

4. Household is willing to take substantial or above average risk with investments in order to earn substantial or above average returns:

1983. $x 50203$ in $(1,2)$

1989. $x 3014$ in $(1,2)$

5. Household is willing to take any risk with investments:

1983. $x 50302$ in $(1,2,3)$

1989. $x 3014$ in $(1,2,3)$

6. Household holds individual stocks outside of retirement plan:

1983. $\operatorname{sum}(0, \max (0, X 50024), \max (0, X 50026))>0$

1989. $\max (0, \mathrm{X} 3915)>0$

7. Household is willing to tie up money to get average or better returns in 1983: x50204 in $(1,2,3)$

8. Household almost always pays credit cards on time:

1983. $\mathrm{x} 50051=1$

1989. $\mathrm{x} 432=1$

9. Household has been turned down for credit or otherwise credit-constrained:

1983. ((x50046 in $(1,3))$ and $(x 50047$ ne 1$))$ or $(x 50048=1)$

1989. $((x 407$ in $(1,3))$ and $(x 408$ ne 1$))$ or $(x 409=1)$ 
10. Marginal tax rate quiz score: abs(NBER taxsim results - x50213)

11. Interest rate quiz score: $\operatorname{abs}(\log (\mathrm{b} 5519)-\log (\mathrm{b} 5521))$. These variables are available on the 1983 SCF only, but can be merged on to the panel. However, since the 1983 SCF does not contain three replicates of each observation, repeated-imputation inference techniques cannot be used with this variable.

\section{Demographic controls:}

1. Natural log of income:

1983. $\ln (\operatorname{sum}(X 50261, X 50263, X 50265, X 50267, X 50269, X 50271$, X50273, X50275, X50277, X50279, X50281, X50283))

1989. $\ln (\operatorname{sum}(X 5702, X 5704, X 5706, X 5708, X 5710, X 5712, X 5714, X 5716$, X5718, X5720, X5722, X5724, X5726))

2. Head has post-college education: $X 5901=17$

3. Head has attended college: X5901 in $(13,14,15,16)$ and no post-college education

4. Head has a high school degree only: X5902 = 1 and no college or graduate degree

5. Head is not white: $\mathrm{x} 5909<5$

6. One spouse is self-employed:

1983. $x 50223=8$ or $x 50243=8$

1989. $\mathrm{x} 4106=2$ or $\mathrm{x} 4706=2$

7. Head is married in 1989: $x 8023=1$

8. Occupation: $x 7401$ or $x 7411$, depending on the spouse participating in the pension

9. Industry: $x 7402$ or $x 7412$, depending on the spouse participating in the pension

10. Firm size: $x 4114$ or $x 4714$, depending on the spouse participating in the pension

11. Job covered by union: $x 4117$ or $x 4717$, depending on the spouse participating in the pension 
TABLE 1: SAMPLE STATISTICS

\begin{tabular}{|c|c|c|c|c|}
\hline & \multicolumn{2}{|c|}{ Unweighted } & \multicolumn{2}{|c|}{ Weighted } \\
\hline & $\begin{array}{l}\text { Participant in } \\
401 \mathrm{k} \text { program }\end{array}$ & \begin{tabular}{|l} 
Participant in \\
other program
\end{tabular} & $\begin{array}{l}\text { Participant in } \\
401 \mathrm{k} \text { program }\end{array}$ & $\begin{array}{l}\text { Participant in } \\
\text { other program }\end{array}$ \\
\hline \multicolumn{5}{|l|}{ Demographics } \\
\hline Mean Age 1989 & 48 & 49 & 44 & 44 \\
\hline Median Income 1983 & 44,000 & $32,100 * * *$ & 32,500 & $25,000 * * *$ \\
\hline Median Income 1989 & 59,400 & $45,000 * * *$ & 50,100 & $37,000 * * *$ \\
\hline $\begin{array}{l}\text { High school } \\
\text { graduate only }\end{array}$ & .24 & $.35 * *$ & .31 & $.43^{*}$ \\
\hline $\begin{array}{l}\text { College graduate } \\
\text { only }\end{array}$ & .40 & .36 & .49 & $.30^{* * * *}$ \\
\hline Graduate degree & .33 & $.17 * * *$ & .16 & .14 \\
\hline Not white & .08 & $.20 * * *$ & .10 & $.20 * *$ \\
\hline Married 1989 & .82 & .76 & .79 & .71 \\
\hline Self-employed 1983 & .11 & .09 & .10 & .07 \\
\hline Self-employed 1989 & .12 & .10 & .07 & .06 \\
\hline Unionized job 1989 & .22 & $.42 * * *$ & .29 & $.45^{* * *}$ \\
\hline \multicolumn{5}{|l|}{ Occupation in 1989} \\
\hline Professional & .55 & $.41 * * *$ & .38 & .29 \\
\hline Technical and sales & .22 & .18 & .27 & .20 \\
\hline Service & .04 & .07 & .07 & .10 \\
\hline Skilled blue collar & .10 & .16 & .17 & .16 \\
\hline Unskilled blue collar & .08 & $.17 * * *$ & .11 & $.25 * * *$ \\
\hline Farmers and forestry & 0 & 0 & 0 & 0 \\
\hline \multicolumn{5}{|l|}{ Industry in 1989} \\
\hline Agriculture & 0 & 0 & 0 & .01 \\
\hline Manufacturing & .37 & .32 & .37 & .34 \\
\hline Trade and services & .57 & .58 & .54 & .54 \\
\hline Government & .06 & .10 & .09 & .12 \\
\hline \multicolumn{5}{|l|}{ Firm Size in 1989} \\
\hline Less than 10 & .01 & $.03^{*}$ & 0 & $.04 * *$ \\
\hline $10-19$ & .01 & .03 & 0 & $.03^{*}$ \\
\hline $20-99$ & .10 & .13 & .09 & .13 \\
\hline $100-499$ & .18 & .15 & .20 & .12 \\
\hline $500+$ & .70 & .65 & .70 & .69 \\
\hline $\mathrm{N}$ & 169 & 282 & $8,732,332$ & $19,325,538$ \\
\hline
\end{tabular}

Notes: *** differences between sample means statistically significant at 1 percent level; ** at the 5 percent level; * at the 10 percent level. Standard errors are adjusted to incorporate imputation uncertainty. 
TABLE 2: SAVING MEASURE MEANS

\begin{tabular}{|c|c|c|c|c|}
\hline & \multicolumn{2}{|c|}{ Unweighted } & \multicolumn{2}{|c|}{ Weighted } \\
\hline & $\begin{array}{l}\text { Participant in } \\
401 \mathrm{k} \text { program }\end{array}$ & $\begin{array}{l}\text { Participant in } \\
\text { other program }\end{array}$ & $\begin{array}{l}\text { Participant in } \\
401 \mathrm{k} \text { program }\end{array}$ & $\begin{array}{l}\text { Participant in } \\
\text { other program }\end{array}$ \\
\hline \multicolumn{5}{|l|}{1983 Saving Measures } \\
\hline "Retirement" main reason for saving & 20 & .16 & 17 & .13 \\
\hline "Retirement" in top 2 reasons for saving & .33 & .28 & .27 & .22 \\
\hline Has an IRA & .48 & $.26 * * *$ & .30 & $.15^{* * *}$ \\
\hline $\begin{array}{l}\text { Willing to take above average or } \\
\text { substantial risk with investments }\end{array}$ & .25 & .22 & .15 & .17 \\
\hline $\begin{array}{l}\text { Willing to take any risk with } \\
\text { investments }\end{array}$ & .73 & .71 & .64 & .64 \\
\hline $\begin{array}{l}\text { Willing to tie up money to earn a higher } \\
\text { return }\end{array}$ & .87 & $.77 * * *$ & .82 & $.71^{*}$ \\
\hline $\begin{array}{l}\text { Holds individual stocks outside of } \\
\text { retirement plan }\end{array}$ & .43 & $.29 * * *$ & .20 & .17 \\
\hline "Almost always" pay credit cards in full & .45 & $.35^{*}$ & .39 & $.27 *$ \\
\hline Has been turned down for credit & .11 & .13 & .16 & .20 \\
\hline Score on interest rate quiz & 1.00 & 1.07 & 1.10 & 1.18 \\
\hline Score on marginal tax rate quiz & 98 & $125^{* *}$ & 119 & 140 \\
\hline \multicolumn{5}{|l|}{1989 Saving Measures } \\
\hline "Retirement" main reason for saving & .37 & $.28 * *$ & .29 & $.18^{* * *}$ \\
\hline "Retirement" in top 2 reasons for saving & .49 & $.35 * * *$ & .40 & $.24 * * *$ \\
\hline Has an IRA & .64 & $.44 * * *$ & .50 & $.32 * * *$ \\
\hline $\begin{array}{l}\text { Willing to take above average or } \\
\text { substantial risk with investments }\end{array}$ & .16 & .12 & .12 & .09 \\
\hline $\begin{array}{l}\text { Willing to take any risk with } \\
\text { investments }\end{array}$ & .70 & .58 & .63 & $.51^{*}$ \\
\hline $\begin{array}{l}\text { Holds individual stocks outside of } \\
\text { retirement plan }\end{array}$ & .47 & $.32 * * *$ & .33 & $.19^{* *}$ \\
\hline "Almost always" pay credit cards in full & .55 & $.45^{* * *}$ & .48 & $.36^{*}$ \\
\hline Has been turned down for credit & .09 & .11 & .11 & .15 \\
\hline
\end{tabular}

Notes: *** differences between sample means statistically significant at 1 percent level; ** at the 5 percent level; * at the 10 percent level. Standard errors are adjusted to incorporate imputation uncertainty. 
TABLE 3: DOES SELECTION EXPLAIN THE SAVING BEHAVIOR OF 401(K) PARTICIPANTS?

\begin{tabular}{|c|c|c|}
\hline \multirow{2}{*}{ Measure of saving behavior in 1983} & \multicolumn{2}{|c|}{ 401(k) Participant in 1989} \\
\hline & Unweighted & Weighted \\
\hline \multicolumn{3}{|l|}{ Interest in saving for retirement } \\
\hline "Retirement" main reason for saving & $\begin{array}{l}.07^{*} \\
(.04)\end{array}$ & $\begin{array}{ll}.06 \\
(.05)\end{array}$ \\
\hline "Retirement" in top 2 reasons for saving & $\begin{array}{l}.05 \\
(.05)\end{array}$ & $\begin{array}{l}.05 \\
(.05)\end{array}$ \\
\hline Has an IRA & $\begin{array}{l}.11^{* * *} \\
(.04)\end{array}$ & $\begin{array}{l}.08^{*} \\
(.05)\end{array}$ \\
\hline \multicolumn{3}{|l|}{ Willingness to take risk with investments } \\
\hline $\begin{array}{l}\text { Willing to take average or above average risk } \\
\text { with investments }\end{array}$ & $\begin{array}{l}.04 \\
(.04)\end{array}$ & $\begin{array}{l}-.03 \\
(.05)\end{array}$ \\
\hline Willing to take any risk with investments & $\begin{array}{l}.04 \\
(.04)\end{array}$ & $\begin{array}{l}.09 \\
(.06)\end{array}$ \\
\hline $\begin{array}{l}\text { Holds individual stocks outside of retirement } \\
\text { plan }\end{array}$ & $\begin{array}{l}-.003 \\
(.04)\end{array}$ & $\begin{array}{l}-.08 \\
(.05)\end{array}$ \\
\hline Willing to tie up money to earn a higher return & $\begin{array}{ll}.04 \\
(.04)\end{array}$ & $\begin{array}{ll}.02 \\
(.05)\end{array}$ \\
\hline \multicolumn{3}{|l|}{ Financial savvy } \\
\hline "Almost always" pays credit cards in full & $\begin{array}{l}. .002 \\
(.05)\end{array}$ & $\begin{array}{ll}.07 \\
(.07)\end{array}$ \\
\hline Has been turned down for credit & $\begin{array}{l}.01 \\
(.03)\end{array}$ & $\begin{array}{l}-.003 \\
(.05)\end{array}$ \\
\hline Score on interest rate quiz & $\begin{array}{l}.04 \\
(.06)\end{array}$ & $\begin{array}{l}.03 \\
(.08)\end{array}$ \\
\hline Score on marginal tax rate quiz & $\begin{array}{l}1.4 \\
(11.2)\end{array}$ & $\begin{array}{l}1.13 \\
(13.8)\end{array}$ \\
\hline
\end{tabular}

Notes: *** statistically significant at 1 percent level; ** at the 5 percent level; * at the 10 percent level. Standard errors are in parentheses and are adjusted to incorporate imputation uncertainty. 
TABLE 4: DOES FINANCIAL EDUCATION EXPLAIN THE SAVING BEHAVIOR OF 401(K) PARTICIPANTS?

\begin{tabular}{|c|c|c|}
\hline \multirow{2}{*}{ Measure of saving behavior in 1989} & \multicolumn{2}{|c|}{ 401(k) Participant in 1989} \\
\hline & Unweighted & Weighted \\
\hline \multicolumn{3}{|l|}{ Interest in saving for retirement } \\
\hline "Retirement" main reason for saving & $\begin{array}{l}.08 * \\
(.04)\end{array}$ & $\begin{array}{l}.08 * \\
(.05) \\
\end{array}$ \\
\hline "Retirement" in top 2 reasons for saving & $\begin{array}{l}.11 * * \\
(.05)\end{array}$ & $\begin{array}{l}.13^{* *} \\
(.06)\end{array}$ \\
\hline Has an IRA & $\begin{array}{l}.04 \\
(.04)\end{array}$ & $\begin{array}{l}.03 \\
(.06) \\
\end{array}$ \\
\hline \multicolumn{3}{|l|}{ Willingness to take risk with investments } \\
\hline $\begin{array}{l}\text { Willing to take average or above average risk } \\
\text { with investments }\end{array}$ & $\begin{array}{l}-.01 \\
(.05)\end{array}$ & $\begin{array}{l}-.02 \\
(.04) \\
\end{array}$ \\
\hline Willing to take any risk with investments & $\begin{array}{l}.01 \\
(.04)\end{array}$ & $\begin{array}{l}-.02 \\
(.06)\end{array}$ \\
\hline $\begin{array}{l}\text { Holds individual stocks outside of retirement } \\
\text { plan }\end{array}$ & $\begin{array}{l}.02 \\
(.04)\end{array}$ & $\begin{array}{l}.06 \\
(.05) \\
\end{array}$ \\
\hline \multicolumn{3}{|l|}{ Financial savvy } \\
\hline "Almost always" pays credit cards in full & $\begin{array}{l}-.01 \\
(.04)\end{array}$ & $\begin{array}{l}-.02 \\
(.06)\end{array}$ \\
\hline Has been turned down for credit & $\begin{array}{l}.01 \\
(.03)\end{array}$ & $\begin{array}{l}.01 \\
(.04)\end{array}$ \\
\hline
\end{tabular}

Notes: ** statistically significant at 1 percent level; $* *$ at the 5 percent level; $*$ at the 10 percent level. Standard errors are in parentheses and are adjusted to incorporate imputation uncertainty.

TABLE 5: IS LENGTH OF PARTICIPATION CORRELATED WITH SAVING BEHAVIOR?

\begin{tabular}{|c|c|c|}
\hline & $\begin{array}{l}\text { "Retirement" main reason } \\
\text { for saving }\end{array}$ & $\begin{array}{l}\text { "Retirement" in top two } \\
\text { reasons for saving }\end{array}$ \\
\hline \multicolumn{3}{|c|}{ Length of 401(k) Participation } \\
\hline $1-2$ years & $\begin{array}{l}.04 \\
(.07)\end{array}$ & $\begin{array}{l}.04 \\
(.07)\end{array}$ \\
\hline $3-4$ years & $\begin{array}{l}.14^{*} \\
(.08)\end{array}$ & $\begin{array}{l}.24 * * * \\
(.08)\end{array}$ \\
\hline $5-6$ years & $\begin{array}{l}.19 * * \\
(.09)\end{array}$ & $\begin{array}{l}.10 \\
(.09)\end{array}$ \\
\hline 7 or more years & $\begin{array}{l}.04 \\
(.06)\end{array}$ & $\begin{array}{l}.10 \\
(.06)\end{array}$ \\
\hline
\end{tabular}

Notes: $* * *$ statistically significant at 1 percent level. Standard errors are adjusted to incorporate imputation uncertainty. Regressions are unweighted. 
TABLE 6: DIFFERENTIAL EFFECTS OF FINANCIAL EDUCATION

\begin{tabular}{|c|c|}
\hline \multirow{2}{*}{\multicolumn{2}{|c|}{$\begin{array}{l}\text { "Retirement" is main reason for saving } \\
\text { Relative to a } 1989 \text { member of the control group who did not list "retirement" in 1983: }\end{array}$}} \\
\hline & \\
\hline 1989 401(k) Participant, did not list "retirement" in 1983: & .03 \\
\hline 1989 member of the control group, listed "retirement" in 1983: & .08 \\
\hline 1989 401(k) Participant, listed "retirement" in 1983: & $.38 * * *$ \\
\hline \multicolumn{2}{|c|}{ "Retirement" is in top two reasons for saving } \\
\hline \multicolumn{2}{|c|}{ Relative to a 1989 member of the control group who did not list "retirement" in 1983: } \\
\hline 1989 401(k) Participant, did not list "retirement" in 1983: & .07 \\
\hline 1989 member of the control group, listed "retirement" in 1983: & .15 \\
\hline 1989 401(k) Participant, listed “retirement” in 1983: & $.35 * * *$ \\
\hline
\end{tabular}

Notes: *** statistically significant at 1 percent level. Standard errors are adjusted to incorporate imputation uncertainty. Regressions are unweighted.

TABLE 7: DO 1983 THRIFT PARTICIPANTS DISTORT THE RESULTS?

\begin{tabular}{|l|l|l|l|}
\hline & $\begin{array}{l}\text { Preferred } \\
\text { specification }\end{array}$ & $\begin{array}{l}\text { Drop 1983 thrift } \\
\text { participants }\end{array}$ & $\begin{array}{l}\text { Drop 401(k) } \\
\text { participants with } \\
7+\text { years of } \\
\text { participation }\end{array}$ \\
\hline \multicolumn{3}{|l|}{} \\
Selection specification
\end{tabular}

Notes: $* * *$ statistically significant at 1 percent level; $* *$ at the 5 percent level; $*$ at the 10 percent level.

Standard errors are in parentheses and are adjusted to incorporate imputation uncertainty. Regressions are unweighted. 


\section{APPENDIX TABLE: UNWEIGHTED REGRESSION COEFFICIENTS FROM TWO SELECTION SPECIFICATIONS}

\begin{tabular}{|c|c|c|}
\hline & $\begin{array}{l}\text { "Retirement" } \\
\text { main reason }\end{array}$ & Held an IRA \\
\hline 401(k) Participant in 1989 & $\begin{array}{l}.07 * \\
(.04)\end{array}$ & $\begin{array}{l}.11 * * * \\
(.04)\end{array}$ \\
\hline Mean Age 1989 & $\begin{array}{l}.01 * * * \\
(.00)\end{array}$ & $\begin{array}{l}.01 * * * \\
(.00)\end{array}$ \\
\hline Log income 1983 & $\begin{array}{l}-.03 \\
(.02) \\
\end{array}$ & $\begin{array}{l}.15^{* * * *} \\
(.03) \\
\end{array}$ \\
\hline High school graduate only & $\begin{array}{l}.04 \\
(.07)\end{array}$ & $\begin{array}{l}.05 \\
(.06) \\
\end{array}$ \\
\hline College graduate only & $\begin{array}{l}.02 \\
(.07)\end{array}$ & $\begin{array}{l}.10 \\
(.07) \\
\end{array}$ \\
\hline Graduate degree & $\begin{array}{l}.02 \\
(.08) \\
\end{array}$ & $\begin{array}{l}.24 * * * \\
(.08)\end{array}$ \\
\hline Not white & $\begin{array}{l}-.09 * * \\
(.05)\end{array}$ & $\begin{array}{l}-.14 * * * \\
(.04)\end{array}$ \\
\hline Married 1989 & $\begin{array}{l}.05 \\
(.04)\end{array}$ & $\begin{array}{l}.02 \\
(.05)\end{array}$ \\
\hline Self-employed 1983 & $\begin{array}{l}-.04 \\
(.06) \\
\end{array}$ & $\begin{array}{l}.01 \\
(.07)\end{array}$ \\
\hline Unionized job 1989 & $\begin{array}{l}-.03 \\
(.04) \\
\end{array}$ & $\begin{array}{l}-.09 * * \\
(.04) \\
\end{array}$ \\
\hline Professional worker & $\begin{array}{l}-.07 \\
(.09) \\
\end{array}$ & $\begin{array}{l}.01 \\
(.08) \\
\end{array}$ \\
\hline Technical and sales worker & $\begin{array}{l}-.09 \\
(.09) \\
\end{array}$ & $\begin{array}{l}-.02 \\
(.08)\end{array}$ \\
\hline Skilled blue collar worker & $\begin{array}{l}-.02 \\
(.10)\end{array}$ & $\begin{array}{l}.08 \\
(.08)\end{array}$ \\
\hline Unskilled blue collar worker & $\begin{array}{l}-.02 \\
(.09) \\
\end{array}$ & $\begin{array}{l}-.03 \\
(.08) \\
\end{array}$ \\
\hline Farm or forestry worker & $\begin{array}{l}.18 \\
(.12) \\
\end{array}$ & $\begin{array}{l}.36^{* * * *} \\
(.12) \\
\end{array}$ \\
\hline Industry: manufacturing & $\begin{array}{l}.24 * * * \\
(.07)\end{array}$ & $\begin{array}{l}.11 \\
(.07)\end{array}$ \\
\hline Industry: trade and services & $\begin{array}{l}.26 * * * \\
(.06) \\
\end{array}$ & $\begin{array}{l}.14 * * \\
(.07) \\
\end{array}$ \\
\hline Industry: government & $\begin{array}{l}.30 * * * * \\
(.08)\end{array}$ & $\begin{array}{l}.05 \\
(.09) \\
\end{array}$ \\
\hline 10-19 employees & $\begin{array}{l}.28 * \\
(.17) \\
\end{array}$ & $\begin{array}{l}-.17 \\
(.16)\end{array}$ \\
\hline 20-99 employees & $\begin{array}{l}-. .00 \\
(.11)\end{array}$ & $\begin{array}{l}-.19 \\
(.13)\end{array}$ \\
\hline 100-499 employees & $\begin{array}{l}.00 \\
(.11)\end{array}$ & $\begin{array}{l}-.23 * \\
(.12)\end{array}$ \\
\hline 500+ employees & $\begin{array}{l}-.02 \\
(.10) \\
\end{array}$ & $\begin{array}{l}-.25^{* * *} \\
(.12) \\
\end{array}$ \\
\hline R-squared & .13 & .35 \\
\hline
\end{tabular}

Notes: $* * *$ statistically significant at 1 percent level; ** at the 5 percent level; * at the 10 percent level. Standard errors are adjusted to incorporate imputation uncertainty. 